DE DE GRUYTER

OPEN
Journal of Intercultural Management

Vol. 7, No. 4, December 2015, pp. 35-53

DOI 10.1515/joim-2015-0029

Łukasz Haromszeki ${ }^{1}$

Wroclaw University of Economics

Piotr Jarco ${ }^{2}$

College of Management "Edukacja”, Wroclaw

\title{
Expected Leadership Competences in the Labour Market in Alumni's Career Paths. A Study in Poland and Other Cee Countries
}

\begin{abstract}
The authors indicate the role of leadership competences as a factor which is a response to the expectations of the labor market. In this presentation, leadership competences are treated as a system of skills existing among leadership relationships. The research of curricula in the best business schools around the world sees leadership as a dynamic, interdisciplinary approach to shaping the organizational reality and they treat this as the main goal of education. Experiences of business schools confirm that leadership skills could only be learnt in a practical approach to teaching, including workshops, simulations, work samples etc. The differences between teaching and market expectations on chosen positions, also in analyzed aspect, called the competence gap, have been studied for the last few years (2007-2013) and co-financed by the UE in the Human Capital Operational Program. After the completion of these projects we have to assume, that we still don't have explicit or complete information about unadjustedness of skills to expectations of positions in chosen trades. The chance of precise identification and defining existing competence gaps is conducting studies of alumni career paths, who in their assessment collate possibilities of learning in business schools with the expectations of employers. Hence in the further part of this article we present the opinions of business school's alumni about competence adjustedness in the domain of leadership skills. The last part of this article is an analysis of similarities and differences
\end{abstract}

\footnotetext{
11lukasz.haromszeki@ue.wroc.pl

2_badania@poczta.onet.pl
} 
between the results of studies conducted in Poland and other CEE countries.

Key words: leadership, competences, alumni, labor market, CEE countries

\section{Introduction}

Culturally organizational behavior differs greatly (different organizational cultures inspired by the systems of norms and values characteristic for various national and regional cultures), but looking at organizational leadership development programs, the best business schools in the world, we find that they share similarities - inspired by ways of training created and carried out in the United States, Britain and France. Poland is no exception to this regard (Financial Times Ranking of Business Schools:2012; Haromszeki, 2012a: 66-80; Haromszeki: 2014a: 81-101).

The most important issue seems to be the answer to the question, if similar ways of training shape leadership competences appropriate to the existing labour market. Leadership according to its own definition is "a relationship superordinate with subordinates (or co-workers, depending on the particular type of organizational leadership), aimed at achieving goals - visions, dreams, plans and values - based on respect and trust of the qualifications of leaders, and often the fascination with them, rational or irrational commitment to the co-created vision of development" (Haromszeki, 2010: 40-41). This type of approach supposes that there are competences systems which are responsible for creating and maintaining a leadership relationship - more complex than a single personality trait, ability, talent etc.

In this article the authors try to present key competences in leadership relationship from the perspectives of different stakeholders of the Polish labour market in context of desired qualifications existing in CEE countries. In last part of the article we present the outcomes about expected skills and existing competence gaps.

\section{Effectual teaching of leadership}

Effectual leadership is based on recruiting followers implementing and coordinating tasks. If we can by using an appropriate type of teaching or diagnosing and reinforcing abilities, skills shape appropriate style of acting with business schools students (inexperience youth and working specialist and managers)? A requirement for directing people in the 21st Century, according to the Hay Grupa research (2014) is inspiring and supporting leadership, based on human capital conception in an organisation (more about factors influencing human capital in organisation, see: Kawka, 2012: 241-249, Suchodolski, 2012: 337-343, Antczak, 2014: 113-132). According to the Hay Group study, over 60 percent high of level leaders are involved in the supporting and managing talents. They also try to teach potential leaders working in different levels and areas of organisations, how to rise from defeat and adapt to a rapidly changing environment. This type of behavior is also a characteristic for the alumni of the best business schools around the word 
(more about them later in this article). According to the Hay Group, the appropriate style of teaching makes different level of leaders, who are well-prepared to take risks and they incur lower personal costs during difficulties, because they treat each defeat as an occasion to learn.

The results from the Hay Grupa are a validation of the ideas presented in literature by C. Sikorski (2006: 76,78), A. K. Koźmiński (2004: 168-169) i B. Kożusznik (2002: 50). According to the above listed authors - a rational leader (related to modern expectations) motivates their subordinates to improve their skills during professional development, shaping their enterprising and innovative thinking and behaviour and also increase the level of their cultural openness. For less independent employees, who feel a need for safety, a leader still plays a role of a guide, who creates situations which reinforce their trust in their own power, decision-making and conflict-solving abilities.

Such an approach is not very common in Polish organizations, because according to conducting research, an autocratic style, which definitely limits the career opportunities of employees, is still preferred by managers and their subordinates (Maczynski, Wyspiański, 2011: 7-18). According to Maczynski, this style is still preferred also by students of management. In recently conducted studies of leadership (Haromszeki, 2014b: 156-166) business school students towards organizational leaders expect (regardless of the level and position in the organization): charisma, effectual impact on others based on their psychological characteristics, responsibility for their action and activity of the team / organization, ease of communicating with people based on oratorical skills and an ability to deal with a situation. Respondents answered that - a leader thanks to his charisma and oratorical skills, efficiently convinces people to their ideas, using a variety of tactics to influence them and expected motivating tools. In addition, the effective leader is a person who when affecting employees, is remembered in a way that ensures their image is invoked in the future of the context of the next task. It is also important that an effective leader binds people together for a long time, thanks to a created and coordinated vision which takes into account the role of each employee involved in each activity. An effective leader, though judged by potential supporters mainly in a rational way, induces a state of long-term emotional involvement with related to these subordinates/coworkers. Similar expectations towards organizational leaders have also Erasmus students coming to the University of Economics in Wroclaw from Spain, Portugal, Italy, Czech Republic, France and Germany. Respondents also admitted that there is a real problem to meet human beings collecting all above presented characteristics in an existing economic reality. There is no precise answer, if there is a problem of curricula or implementation of them in organizational realities.

We could assume that the problem with implementation of these tasks is based on insufficient financial means used in educational systems existing in CEE countries 
and preferred way of teaching - more theoretical than practical (McKinsey Global Institute, 2013; Agrotec, 2014 r.). The best business schools around the world don't have this problem (Haromszeki, 2012a: 66-80). Implemented programs aimed at young people and experienced managers are executed in different number of hours, depending on the level and expectations of participants (from a few weeks for specialist courses to full-time two-year management studies). Tailored to individual needs, the programs are designed to shape the future organizational leaders in accordance with information presented by the universities, results in a very high percentage of people achieving success in managerial positions after graduation. It is no wonder - after all, these are the world's best business schools. The careers of graduates are more specifically described in the articles, linked with the website of each university. The popularity of analyzed courses are due to several key factors. First of all - past successes of alumni inspired future students to achieve a successful individual career in the business world. Secondly - these schools offer programs, which are flexibly adapted to the changing organizational world. Thirdly - according to the latest research results, selected universities argue that they teach complex educated leaders, and are prepared to make informed decisions in a variety of social, cultural, economic and market conditions (not trained craftsmen - people programmed to perform rehearsed in college patterns of action, but a person having creative, active and integrated thinking, which encourages current and strategic actions). Fourthly - great strength and competitiveness of the investigated business schools are their graduates because the feedback from them, which is the basis for updating the curricula, they collaborate with the university in organizing internships for students, support their school - essentially, financially and morally - confirming that the capital of relation is the most important resource of all individuals, who are successful in leadership.

During correlation of curricula, there is important to take into account results of Kotian, Arokszallasi, Rzentarzewskiej study (2014). According to their research the main indicator of economic development is not related with the amount of alumni who start working in the labour market, although other statistics present correlation between economic development and increasing number of alumni with a university degree. This relation could be misleading. For example Austria has a share of university graduates similar to CEE, while being much more developed (Kotian, Arokszallasi, Rzentarzewska, 2014: 15). More important than the amount of alumni with University degrees seems to be the quality of teaching - creating and implementing in each university according to the changing economic and market determinants as application of the idea of long-life learning. According to a presented study, the amount of years spent during training seems to correlate strongly with the level of economic development. In this aspect, to improve the present situation in CEE countries, there is a need to intensify an implementation of 
system solutions, especially in Romania, Croatia, Hungary and Slovakia. According to the latest data, the Czech Republic is improving in this field, increasing the share of working-age population in training. (Kotian, A rokszallasi, Rzentarzewska, 2014: 15). The OECD study, in which they use the PISA (Programme for International Student Assessment) scoring system, are not analyzing an amount of hours and people in process of teaching in educational systems in CEE countries, but mainly - the quality of these systems. Original PISA scores are just one part of the whole system of actions. An OECD study shows that there are significant differences between original PISA scores and the program of so-called "problem solving skills of students". According to conducting studies, Serbia, the Czech Republic and Slovakia are doing well in this respect, as students from these countries perform better, or at least roughly as would be suggested by their original scores, in problem solving. Poland, Hungary, Slovenia and Croatia, on the other hand, show significant gaps, indicating that students in these countries struggle to use all the skills that they demonstrate in other domains when asked to perform problem-solving tasks. This suggests that a reshuffle, and not necessarily more spending, could significantly improve the efficiency of the system if it focused more on problem-solving instead of teaching as much lexical material as possible and testing that material extensively. If we take a look at this problem in dynamic terms, we could see that in Poland we have observed significant improvement over several years. Poland in the general ranking of PISA overtakes other CEE countries, because more and more schools are ready to follow expectations of the Polish economy (Kotian, Arokszallasi, Rzentarzewska, 2014: 16).

According to the results of another study (The Korn/Ferry Institute, 2009) conducted in CEE countries, expectations towards organizational leaders are similar in different states in this region of Europe. Similarly in CEE countries the main expectation towards organizational leaders is knowledge of the English language (and other foreign languages) and the skill of using them. Predominantly is the conviction that leadership skills are unteachable (70\%), although respondents admit that the quality of teaching has increased intensively over the last 10 years. Still young management study's alumni and managers are short-term minded, but they start using a strategic approach and talent management in their organizations, teams etc. The main difference, which has the biggest impact on this analysis is the assessment of quality and effectuality of the educational system. Researchers found that over 60 percent of the Czech and Slovak Republics respondents believes that their educational institutions were failing in the leadership skills learning processes. There is a different situation in Poland, where almost 70 percent of respondents are convinced that "their institutions were equipping their graduates with the necessary leadership skills".

The expectation of management students towards future organizational leaders presents, the study Values and Leadership Expectations of Future Managers 
from Transforming Societies" (Čater, Lang, 2011). In the Czech Republic and Romania the most important expectations towards organizational leaders is to be an effective bargainer (negotiate effectively, intelligently and always being well informed). In Czech, Slovakia and Romania all preferred leadership dimension is team oriented leadership, but only in the Czech Republic and Romania respondents expect charismatic leadership. There are also important differences. According to the Czech respondents the expected organizational leader apart from being a good bargainer should also be inspirational, diplomatic and able to boost morale, decisive, communicative, trustworthy, interested in temporal events and act logically. They should also be dynamic which means highly involved, energetic and enthused, visionary, team integrator. (Compared with middle managers from the Czech Republic, several East European countries e. g. Hungary, Poland and Slovenia of GLOBE project in 2004, Czech Students give less emphasis on teamoriented and participative leadership behavior). Romanian students presented a list of expectations similar to their Czech colleagues. For Romanian respondents an effective leader should be, besides a bargainer, diplomatic, intelligent, communicative, administratively skilled, coordinator, inspirational, be able to motivate, trustworthy, decisive, informed, team builder and dependable. Slovaks are definitely more people oriented than other nations being a part of the research sample. According to their expectations the most effective and worthy leader to follow has these characteristics: kindness toward others, the ability to unify people, diplomacy, visionary, inspirational, and administratively competent, with personal integrity, performance oriented and decisive, should think about the future and be strongly performance oriented through empowering team-work and teamspirit, should empower decentralization, informal relations and lose control in organizational environment, should invite their subordinates taking initiatives; sustain participation of team members in decision-making as well as pragmatic and open relationships in teams.

Furthermore, researchers from the National Center for Research and Development, calls for the academics and labor market participants pay attention to this troublesome phenomenon. Soon, in the labor market, could start a huge competence gap - especially in the category of leadership or at least management skills. Most of the functioning companies in the Polish market were started at the beginning of the 1990's by people even older than 30-40 years olds. Now they are almost at retirement age and we could observe very soon in the Polish business world a problem with management succession and an increasing demand for managers and management and leadership competences (in the BKL14 - the study of human capital in Poland - called managerial and interpersonal competences) (Agrotec, 2014: 38). The problem, as the creator of the Report does not mention, is the result of owners and managers approach to education of their successors. 
It is obvious that in a situation in which autocratic style dominates (lack of task and responsibility delegation) (Maczynski, Wyspianski, 2011) there is low level of confidence (hiding important information) (Czapiński, Panek, 2013, ESS, 2014), preparation for succession may not take place.

Authors of the Report claim, that a trend which should also be considered in assessing the need for competence, is a paradigm shift in productivity. Developed countries, if they want to maintain the standard of living and necessary for this purpose is GDP growth of $2-3 \%$ per annum, must dramatically increase the productivity of their economies. The only possible way is through innovation. In this meaning innovation is strongly related to demand for appropriate competences. In this regard, the European Commission indicates that Poland has to cope with the problem of an unattractive research and innovation system and low innovation potential of Polish SMEs (Agrotec, 2014: 39). Innovation can often occur in organizations where there is organizational leadership - involving the creation and the use of ideas aimed at the dynamic development of the organization based on a strategic approach, flexibility and courage in taking calculated risks.

Another trend presented in this report, which is a summary of activities in the years 2007-2014 and the extrapolation of the observed phenomena, is associated with the development paradigm of the network society, both in terms of communication, and organization. Above are the presented tendency causes an increase in demand for competencies related to communication in the virtual world, also in the business and managerial domains. As indicated by the creators of the Report, it creates, above all, a new dimension of educational needs and challenges within the interpersonal and cognitive competences, closely linked to the ability to use a new and converged media. In this context, the authors of the Report highlights a certain incompatibility BKL competency model in this situation. Appropriate communication skills associated with the presence on the network should be a subset belonging in part to two sets - social and technical competences (Agrotec, 2014: 39).Please remind the authors of the Report, "in an organizational sense a network society is changing the hierarchical management models and organization of work into the network formula, in which the traditional meaning of work is less important than activity in a couple of different projects at the same time. Whence project management methods are useful in a particular industry would become an important part of their knowledge and skills (Agrotec, 2014: 39). Besides a new role starts playing a leadership based on different expectations than useful in traditional relationships.

As has been described in previously published articles, there is a social conception of two types of leaders - in the traditional and virtual (Internet) relationships (Haromszeki, Jarco, 2013: 200-216). The most often indicated feature characterising a leader in the world of virtual relations was creativity (inventiveness) (78.1\%), which 
was interpreted mainly as the ability to introduce all types of innovations (novelties). According to the respondents, it was the quality which determined the most success in leading others. Regardless of the type of a given activity of a leader on the Web, such a leader - according to the respondents' opinion - has to be able to introduce innovations and show more than average inventiveness which will attract others. Another feature that was specified many times included the persuasive skills (67.5) of which the abilities to manipulate the addressees, in particular - their emotions. A separate category defined by the surveyed persons included the ability to make the addressees interested (65.8\%), that is to interest the followers identifying with the leader in one way or another. The analysis of the empirical materials reveals that - in some dimension - the ability to make people interested (including shocked) was identified with creativity by the surveyed people. This category was singled out as a separate feature at the stage of data analysis. Another important feature characterising a virtual space leader is constant readiness to communicate, interactivity and availability of a leader. Due to the specificity of virtual relations, it is a significant feature for $57.9 \%$ of the surveyed people. The features mentioned later included interdisciplinary knowledge (45.6\%), ability to anticipate $(38.6 \%)$, and charisma (16.7\%). While, for traditional relationships, the most frequent answer was charisma - 68,4\%. It is worthwhile to add that the analysis of the answers included in the questionnaires shows that the respondents identified charisma of a leader in the world of traditional relations with strong personality and sanguine temperament. In the respondents' opinion, a traditional relation leader is best characterised with the psychological desire to dominate (expansiveness in relations with people and more than average need of event controllability). It is a feature necessary for being a leader for $57 \%$ of the respondents. Almost half the respondents (44.7\%) indicate the psychological stability, equilibrium and resistance to stress of a non-virtual world leader. The features mentioned later included firmness (40.4\%), ability to speak (34.2\%), and objectivity in interpersonal relations (15.8\%) (Haromszeki, Jarco, 2013: 200-216).

In addition to the expectations of graduates and employers, a very important issue undertaken by various research diagnosing the level of preparedness of workers to perform tasks at the workplace are competency gaps. Competency shortages (BKL) recorded for i.a. management positions are concentrated in three categories: general professional, self-organizational, interpersonal and cognitive competences. As shown by the authors of the BKL, in the subsequent editions of the study they concluded that the level of shortage of competence in the field of interpersonal and cognitive skills slightly decreased, but increased shortage of selforganizing competence. They observe that need for professional competences has increased lately a lot. This situation may provide an opportunity for graduates in case of further improving the quality of education. Universities may also, within the framework of learning outcomes seek to strengthen the competence of self- 
organizing (primarily business), which were suggested by employers (Agrotec, 2014: 42). The barrier to use innovative educated graduates may be on the side of employers. Frequently it results from a tendency to stereotype and negative evaluations of graduates. As indicated by the creators of the Report - solution in this area could be the development of professional recruitment services, provided by both university career offices, as well as by specialized companies. (Agrotec, 2014: 44). Respondents said, that universities provide education in a relatively narrow specialization, while in 2020 perspective they needed a broader, multi-disciplinary skills necessary for proceeding technological change. (Agrotec, 2014: 44).

As indicated by the authors of the Report - in the National Foresight Programme Poland 2020 (2009) formulated five scenarios, possiblely depending on specific factors, according to which will increase or decrease the demand for specific types of competences. In the case of the first scenario ("leap"), as indicated by the authors of the Report, is expected to increase the demand for competencies and qualifications useful in the context of the Knowledge Based Economy (KBE). This scenario assumes rapid acceleration of economic changes, which may mean the rapid obsolescence of knowledge acquired at university and to some extent also qualifications. Conducted analysis shows that under the first scenario, rapid adaptation to changes in the labor market would be the most expected competences (Agrotec, 2014: 62). In the case of a "hard adjustment" scenario it is assumed that the ability to produce the intellectual capital and general capital of competencies in Poland will be greater than the ability of the economy to its absorption. This situation would often result in continuing abroad careers of the best employees, including scientist and academics. Authors of the Report emphasized that above described trend will be visible only in situation in conditions of favorable external situations, but socio-economic change will be met with growing public resistance. The Polish economy will remain a relatively competitive economy (e.g. due to low labor costs and skilled personnel in various sectors). The scenario "difficult modernization" refers to conditions in which the global and European financial and economic crisis turns into a permanent phase. According to the experts of this Program the best solution for this situation is thorough reconstruction of the system of knowledge, diversification of the energy sector and maintaining modernization trends in the economy, supported in the first phase by European funds. The implementation of such a scenario in terms of global and European crisis is mainly conditioned by the liberation of a strong social energy (increased social capital) favorable to change, and parallel, courageous attitude of the rulers. None of these factors, as emphasized by the creator of the report, will cause in the fourth crisis scenario called "declining development" or going further - "collapse" (scenario 5). Failure to use relatively good, despite the global crisis, the economic situation for the country, will probably lead to a regression of knowledge system, the outflow 
abroad of young staff with the highest competences and qualifications, remain low innovativeness of Polish the economy, and the traditional factors of development (e.g. a cheap labor force) will stop playing an important role. The report noted that the competencies associated with the ability to adapt to changing conditions, will become unsuitable during stagnation. The strongest positions will have those who will inherit the relatively better professional competences. (Agrotec, 2014: 62-63) a The above described situation is partly today prevalent in Poland. However, the situation is definitely better mainly thanks to European funds for innovation and building science - business cooperation.

Both studies National Foresight Program Poland 2020 (2009), as well as strategic documents (National Development Strategy 2020, a Long-term Development Strategy of the Polish 2030., Report Poland 2030 - Development Challenges), forecast that one of the decisive factors of development in Poland will be social capital, currently remains at a low level, which is a barrier to development. The level of social capital would cause a "difficult modernization" or a "declining growth" scenarios. Authors of the strategic documents emphasized that the most important are competences related with the organization of public life and civil society. There is a need for designation e.g. a subset of competencies related to modern formula of leadership in categories: managerial and interpersonal competences (Agrotec, 2014: 64). Such measures are already taken, and one can observe the development of civil society led by local leaders (Haromszeki, 2011a, 2011b, 2012b). The conducted studies confirm that, the most important are communication skills, including foreign languages (especially English).

Looking at the needs of employers - the decision-makers implementing the potential of employees in actual organizational conditions, it is noted that they articulate the five most desirable competences, which should be well equipped graduates. These include competencies: cognitive, interpersonal, use of language, computer skills and self-organization. From the perspective of employers, knowledge and ability to apply it are not key elements in finding work for graduates. They admit that definitely more important are competences related to the adaptation and processing of information and their communication to individuals and groups (Agrotec, 2014: 85). Employers indicate that competency gaps exist especially in categories: interpersonal, self-organization and cognitive skills (Agrotec, 2014: 86). They suggest that preparing graduates to a higher standard to meet the need of the labor market could appear only by increasing the number of practical classes, mandatory practice, internships and enhance cooperation with enterprises (Agrotec, 2014: 109). They add, that it is worthwhile to take inspiration from best practices of foreign business schools, e.g. the US, in terms of inducing interest in the topic and awareness of young people that they learn for themselves (see also: Haromszeki, 2012: 66-80). This is very interesting idea, but Polish universities have to create their own way of practical teaching taking into account existing context 
and expectations. Suggested by respondents increase of teamwork, creativity and the practical work within higher education programs (Agrotec, 2014: 112), have been using in for example classes of leadership for last couple years (Haromszeki, 2014b).

According to the BKL 2014 (fourth edition - Similar results were also obtained in the fifth edition of the study - Partial results were presented at a conference in Warsaw on 28 April 2015) for managerial positions required by employers competences in 2014 were: self-organizing, professional, interpersonal and cognitive. Analysis of the demand for competencies in the BKL points to key competences and the relative difficulty of obtaining them in the labor market. Analysis of supply presents prepared by universities the evaluation of the level of achievement learning outcomes required by the business. The main element of the balance sheet is a summary of these two perspectives. One of the major conclusions of the BKL report is that the difficulty to recruit people with specific competence is not determined solely by the quality of education, but also is closely related with the quality of recruitment and selection process or the employers brand. In the BKL 14 researchers emphasized that "achieved learning outcomes relate to the average level of" average student ", which means that the walls of the university leaving both better and worse graduates than may result from the intended learning outcomes" (BKL, 2014: 70). The largest competency gap in the BKL exists in the BPO / SSC - as much as 55\% competences is assessed as difficult to obtain on the one hand, and educated at the universities on the other. c The competency gap in the BPO / SSC focuses on soft skills such as communication skills (oral and written), team work, cross-cultural sensitivity, adaptation, focus on goals or influencing others. The creators of the BKL emphasize that this type of competences requires adequate tools and methods of teaching and opportunities existing at university (scientific circles, study tours, internships, projects etc.). These possibilities exist at different type of universities in Poland, but according to authors of the BKL 14 functioning system leads to the reproduction of inequality. Participants of different programs (e.g. Erasmus) are students who already have appropriate skills of building social and cultural capital. Those who do not have the initiative and do not know how to work in a group do not decide to establish a scientific circles or go abroad. In this meaning they are part of a category of people called by representatives of companies "unemployable". It seems that above described group, instead of beneficiaries of the educational "St. Matthew Effect" - should be the target audience for alumni competences improvement programs (BKL, 2014: 70). Additionally it is worthwhile to emphasize that students of ordered and unordered courses evaluate the preparation for the use of knowledge into practice. This is worrying situation, because the ordered courses should be prepared according to precisely listed expectations of topics, methods and implemented in cooperation with enterprise or group of companies (BKL, 2014: 160). 
Research results presented in the first part of the article clearly show that the most anticipated in the labor market (Polish and others) are social skills that could be considered for purposes of analysis (according to definition of "leadership relationship") - system of leadership competencies. The dominant skills in above described system are: self-organization, communication, including language skills and a creative approach to work and build relationships with other people. These are the competencies expected in Poland and other CEE countries analyzed in this article, but still not present in the labor market in this region of Europe. They are characteristic more for graduates of the top business schools around the world, than alumni of universities functioning in CEE countries.

\section{Methods}

\section{Introduction}

As mentioned in the first part of the article, the dynamics of changes in the labor market means that one must flexibly adjust competences to changing conditions. Education of these competences can be carried out in two ways: by teaching technical skills (professional) in response to demand diagnosed thanks to alumni's carrier paths study and the training of interpersonal and conceptual skills that will help adapt to new conditions, regardless of the scope and nature of the changes.

Alumni's carrier paths study has become common practice in developed countries. Most often the practical aim of these activities is the need to adapt the content and forms of education to labor market needs. Previously universities didn't construct curricula suited to the needs of economies and wider market trends in the CEE countries. This situation is changing due to globalization of the higher education sector and specific solutions used in developed countries. The number of research initiatives and constantly observed increase of awareness in this regard in the long run, will certainly contribute to improving the employment rate among graduates.

It is widely recognized today that the completion of specifics of higher education does not specify a profession already performed for life. In the case of rapid obsolescence of knowledge that graduates may acquire in the course of study, other important dimensions determining the position of a young people in the labor market (Jarco, 2012: 370-391). The role of a modern educational system is, therefore, the formation of certain attitudes e.g. efficient adaptation to labor market trends. Experienced employers expect from new employees, above all, high intellectual and adaptation skills. Theoretical knowledge becomes merely an additional asset, which helps a graduate quickly to adapt to the specifics of the company and the nature of work. It should be noted that the characteristics of modern workers in social competences categories, largely refer to broadly defined leadership competencies 
- which are the basics of creating and maintaining leadership relationships (more about this at the beginning of the article).

Thus, in the context of increasingly valued by the world of work characteristics and attitudes of leadership should conduct research that attempts to diagnose and analyze possibility of acquiring and developing this competences in existing system of education.

\section{Research methods}

This study was conducted in June 2015. The method used was the questionnaire interview method (CAWI).

\section{Purpose of the study}

The aim of the study was to measure selected issues that make up the image of university of economics graduates. In particular, the main goal and most important part of the study was to determine the respondents' opinions about the desired characteristics of modern organizational leaders. The key question is also to what extent universities allow student faculties to develop these competencies.

\section{Sample}

Respondents had completed their studies (bachelor and master) of economic profiles in the 6 selected private and public universities from the area of Wroclaw. Those tested were a total of 225 persons with higher education. $78 \%$ of graduates in the sample had completed specialties such as Human Resource Management, Business Management, Logistics Management. Respondents were working in enterprises with Polish companies or enterprises with the Polish capital majority $(40.6 \%)$ and companies with foreign capital or a majority of foreign capital $(23.7 \%)$. $32.4 \%$ of the respondents work in public organizations. 3.4\% participants of this study or work abroad. The online questionnaire was mostly filled in by young people (under 30 years old $-60 \%$ of the sample). Half of the respondents are unmarried. Most respondents live in the Wroclaw metropolitan area.

Table 1. Respondents

\begin{tabular}{|l|l|l|}
\hline Sex & Amount & $\%$ \\
\hline Man & 59 & 26,2 \\
Women & 166 & 73,8 \\
\cline { 2 - 3 } Total & 225 & 100 \\
\hline Age & Amount & $\%$ \\
\hline
\end{tabular}




\begin{tabular}{|c|c|c|}
\hline \multirow{2}{*}{$\begin{array}{l}\text { Up to } 30 \text { years of age } \\
\text { Over } 30 \text { years of age } \\
\text { Total }\end{array}$} & $\begin{array}{l}135 \\
90\end{array}$ & $\begin{array}{l}60 \\
40\end{array}$ \\
\hline & 225 & 100 \\
\hline Marital status & Amount & $\%$ \\
\hline \multirow{3}{*}{$\begin{array}{l}\text { Unmarried } \\
\text { Married } \\
\text { Total }\end{array}$} & 113 & 49,8 \\
\hline & 112 & 50,2 \\
\hline & 225 & 100 \\
\hline Place of residence & Amount & $\%$ \\
\hline \multirow{7}{*}{$\begin{array}{l}\text { Wroclaw } \\
\text { Lower Silesia - other city/town } \\
\text { Lower Silesia - village } \\
\text { Other voivodship - city/town } \\
\text { Other voivodship - village } \\
\text { Abroad } \\
\text { Total }\end{array}$} & 67 & 29,8 \\
\hline & 74 & 32,9 \\
\hline & 46 & 20,4 \\
\hline & 18 & 8 \\
\hline & 14 & 6,2 \\
\hline & 6 & 2,7 \\
\hline & 225 & 100 \\
\hline
\end{tabular}

Source: own study

\section{Opinions about expected leadership competences - own study results}

In the study, first of all, graduates were asked to identify the characteristics of modern workers, which are expected in the labor market. Respondents ranked the answers by using five-step scales for each category. In the opinion of graduates in the labor market are currently the three most valued worker's characteristics: independence (4.65); professionalism (4.41) and self-confidence attitude (4.24). Further mentioned were loyalty (4.22), the ability to cooperate with others (4.14), systematicity (4.14), power/ passion (4.1), reliability (4.06) and adaptability (4 03). With the proposed set of categories were the lowest rated characteristics such as honesty/ righteousness (3.98), dedication (3.93), the ability to anticipate the facts (3.81), readiness for further education (3.78), individualism (3.35) and competition (3.07) (The graph below) These results show that the features particularly valued in the labour market is likely to help workers find themselves in the labour market regardless of the development scenario proposed in the Foresight Poland 2020. The dominant features characterize leaders, people who are independent, confident, carrying out operations in cooperation with other people in different levels and areas in the organization. However, comparing these results, particularly in terms of characteristics such as honesty/ righteousness and readiness for further education, we find that in the process of shaping the respective competencies of leadership and development of civil society, Polish people/managers are still in the early stages (Ravishankar, Hudson, 1999: 233-236). As mentioned earlier, 
there is positive phenomena of development in local communities, but they are not transmitted to the level of more general values and norms.

Graph 1. Valued employee's features in the Polish labour market - opinions of business (management, economical) faculty - summary statement (\%) (N-225).

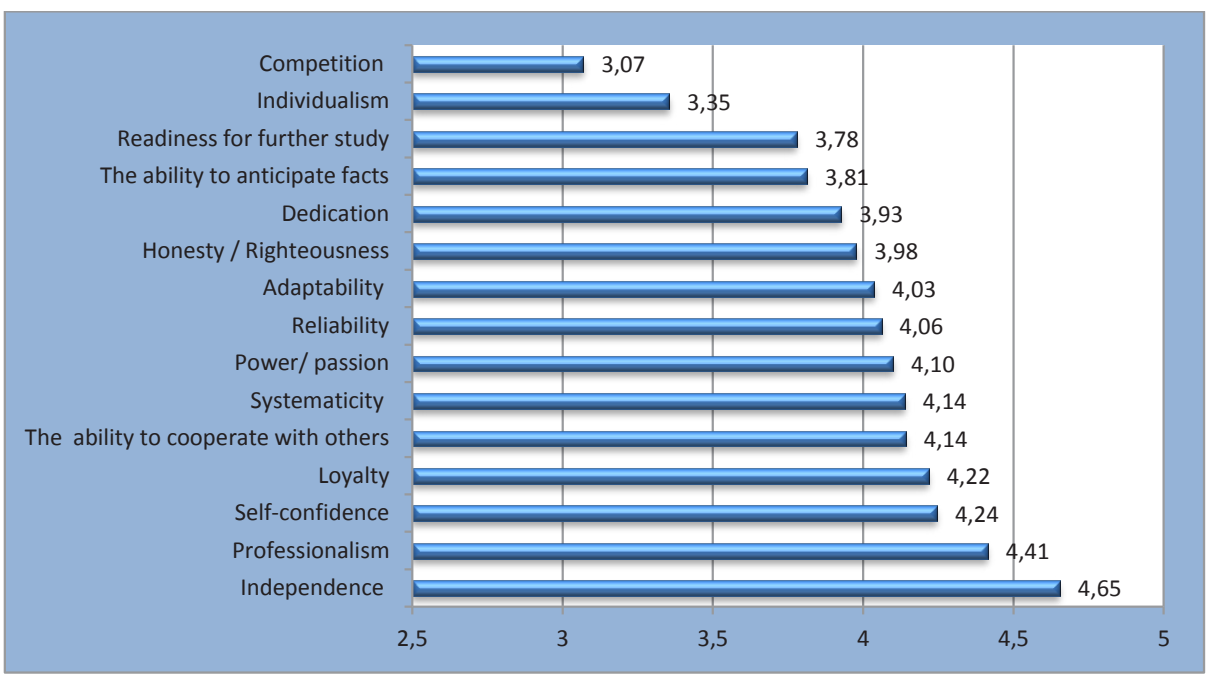

Source: own study

Later in the research, during the pilot study were selected these features which, according to respondents predispose to being an efficient manager and a leader in the workplace. That question was: To what extent today employers attach importance to the following skills/ knowledge and the extent to which the university has allowed to acquire specific skills during the studies? In this perspective, the most desirable features of leaders in organizational cultures, in which graduates work are: the ability to cope with stress (83.25\%), processing and use of knowledge in practice (79\%) and communication competences understood as self-presentation skills (77.25\%).

Table 2. An Assessment of employee's expectations in relation with the possibility of acquiring chosen competence during w business(management, economic) studies - summary statement $(\%)(\mathrm{N}-225)$.

\begin{tabular}{|l|l|l|l|}
\hline Social skills and competences & $\begin{array}{l}\text { Opinion of } \\
\text { employees about } \\
\text { their employers } \\
\text { expectations }\end{array}$ & $\begin{array}{l}\text { Assessment of } \\
\text { possibilities } \\
\text { of acquiring } \\
\text { knowledge/ } \\
\text { competences in the } \\
\text { course of study }\end{array}$ & Gap \\
\hline The ability to cope with stress & 83,25 & 55,75 & 27,5 \\
\hline
\end{tabular}




\begin{tabular}{|l|l|l|l|}
\hline Language skills (foreign languages) & 63,0 & 46,0 & 17,0 \\
\hline Project management & 67,0 & 52,75 & 14,25 \\
\hline Entrepreneurial skills and attitudes & 70,0 & 58,0 & 12,0 \\
\hline Self-presentation skills & 77,25 & 65,5 & 11,75 \\
\hline $\begin{array}{l}\text { Processing and use of knowledge in } \\
\text { practice }\end{array}$ & 79,0 & 68,5 & 10,5 \\
\hline Team management & 62,5 & 62,25 & 0,25 \\
\hline $\begin{array}{l}\text { The ability to draw up the analyses, } \\
\text { reports and research }\end{array}$ & 60,5 & 64,25 & $-3,75$ \\
\hline
\end{tabular}

Source: own study

This question, is to try to identify the key leadership skills and competencies, particularly desirable in the labor market, was created to verify the extent to which universities of economics prepare students for leadership roles. In practice the, competency gap is the best measure of conformity between the needs in this area and the actual educational offer. These gaps, in the accepted meaning are perceived as a discrepancy between what could have been learned in the course and what modern business expects from respondents their employers, and the Polish labour market in general. So it is not objectified measurement (assessment) of the competency parameters actually acquired by graduates but only an assess of the adjustment of the educational offer to the realities of the local labour market.

The most significant gap identified in the study relates to the field of coping with stress (27.5\% gap). Analysis of additional open-ended questions leads to the conclusion that the respondents understood this category more broadly as stress management in the workplace (both their own stress and stress of their coworkers). A significant gap can be observed also on the level of language competences (gap - 17\%) and in the area of project management (gap 14.25\%). Team management as a leadership competency has a gap of $0.25 \%$. In the case of diagnostic and analytical skills needed for preparing different specialist documents (analyzes and reports) we can observe a negative gap $(-3.75 \%)$. In the opinion of graduates, this specific category of skills was during the educational process more stressed than required by companies in which respondents are currently working.

The above presented set of eight categories of employers' expectations were chosen based on a pilot study and certainly does not exhaust all the major areas that make up the effective training of people for leadership, we understand that there is as an attitude necessary to build this type of relationship. It should be noted, that competences such as coping with stress or self-presentation skills are, according to respondents experiences, the most important issue in the labor market. The observed gaps indicate the need for a stronger emphasis of these competencies in the educational process. The legitimacy of such actions is confirmed by the results of numerous studies conducted in CEE countries (see: Erste Group Research, 2014; BKL, 2014; Agrotec 2014). 


\section{Conclusion}

Summarising the analysis of various reports of national and international research and own studies conducted this year, can be seen that, most of the respondents in CEE countries is to be able to list the competencies needed to play a role of an effective organizational leader with understanding of existing cultural, economic and market conditions. However, respondents in different studies admit that there is a real problem to acquire them within the framework of higher education. Existing differences in the effectiveness of education in the best business schools in the world and universities in CEE countries is due to a number of factors. Firstly - there are not sufficient financial resources. Secondly - wishful formulation of programs and lack of coherence between the curricula and their implementation. Thirdly - lack of practical classes in the total number of training hours. Fourthly too little involvement of students, who do not believe in the success of their future career. Fifthly - the lack of real cooperation of business and universities, consisting not only of folding wishes, but also participation in the financing and provision of jobs, not just short-time practice.

The desired leadership competencies, as can be expected, if they are consistently and effectively taught in the educational process, it would allow to shape an organizational reality, regardless of the scenario of development proposed in the Foresight Poland 2020.

\section{References}

Agrotec, (2014) Analiza kwalifikacji i kompetencji kluczonych dla zwiekeszenia szans absolwentón na rynku pracy, RAPORT KOŃCOWY, Warszawa, 2014 r.

Antczak Z., (2014), W strone koncepcji kapitału ludžkiego, w: Przyszłość zarządzania zasobami ludzkimi. Dylematy i wyzwania / Antczak Zbigniew, Borkowska Stanisława (ed.), Difin, Warszawa. Bilans Kapitału Ludzkiego (BKL), (2014), Kompetencje Polakón a potrzeby polskiej gospodarki. Raport podsumowujący IV edycję badań BKL z 2013 r. (ed.) J. Górniak, PARP, Warszawa.

Čater T., Lang R., (2011), Values and Leadership Expectations of Future Managers from Transforming Societies, Chemnitz University of Technology, http://www.tu-chemnitz.de/wirtschaft/ bwl5/forschung/schriften/doc/16.pdf: 5.01.2013.

Czapiński J., Panek T. (red.), Diagnoza społeczna, raport, 2013, www.diagnoza.com.

Dlugookresowa strategia rozwoju Polski do 2030 r., Trzecia fala nowoczesności, (2013), Ministerstwo Administracji i Cyfryzacji, Warszawa 11 stycznia 2013.

Emerging markets, emerging leaders. A Talent and Leadership Study of Central and Eastern Europe, (2009), The Korn/Ferry Institute, http://www.trainings.ru/f/1/pics/CEE_Talent _ Ldrshp_Study.pdf: 5.01.2013. 
Europejski Sondaż. Spoteczny (ESS), (2014), http://civicpedia.ngo.pl/wiadomosc/955642. html, 27.08.2015.

Financial Times Ranking of Business Schools, http://rankings.ft.com/businessschoolrankings/ global-mba-rankings-2012: 16 Aug 2012.

Haromszeki Ł., (2014a), Expected features and the behavior of talented leaders in the three sectors of the Polish economy in context with other Central-Eastern European Countries, Journal of Intercultural Management (ed. Ł. Sułkowski), Vol. 6 No. 4 December.

Haromszeki Ł., (2012), Aktywność liderów jako szansa rozwoju organizacji trzeciego sektora w powiecie dzierźoniowskim, Determinanty potencjału rozwoju organizacji (ed.) A. Stabryła, K. Woźniak), Mfiles.pl Encyklopedia Zarządzania, Kraków.

Haromszeki Ł., (2011), Liderzy lokalni w kontekśsie barier administracyjnych w zarzadzaniu gmina, Dysfunkcje i patologie w sferze zarządzania zasobami ludzkimi, Tom 4, (ed.) Z. Janowska, Wydawnictwo Uniwersytetu Lódzkiego, Łódź 2011a.

Haromszeki Ł., (2014b) Przywódz̨two organizacyjne drugiej dekady XXI wieku - szansa na budowanie kapitału ludzkiego w organizacji, Prace Naukowe Ue we Wrocławiu nr 350, Sukces w zarządzaniu kadrami. Różnorodność w zarządzaniu kapitałem ludzkim - podejścia, metody, narzędzia, Problemy zarządczo-psychologicznych (ed.) Marzena Stor, Agnieszka Formalczyk, Wydawnictwo UE we Wrocławiu, Wrocław.

Haromszeki Ł., (2010), Przywództtwo w czasie kryzysu, w: T. Listwan, (ed.), Zarządzanie w sytuacjach kryzysowych podczas Euro 2012, Wydawnictwo Uniwersytetu Ekonomicznego we Wrocławiu, Wrocław.

Haromszeki Ł., (2011b), Skuteczni liderzy lokalni, Efektywność zarządzania zasobami ludzkimi, (ed.) B. Urbaniak, Wydawnictwo Uniwersytetu Lódzkiego, Łódź.

Haromszeki L., (2012a), The teaching of leadership - ways to create leaders in selected universities in the world, Journal of Intercultural Management, Vol. 4, N. 3, September, Łódź.

Haromszeki, P. Jarco, (2013), Psychological and social competences characteristic of virtual space leader, Proceedings of the Second International Conference on ICT Management for Global Competitiveness and Economic Growth in Emerging Economies, September, Wrocław.

Hay Group, (2014), Best Companies for Leadership http://www.haygroup.com/ bestcompaniesforleadership/research-and-findings/about-the-research.aspx, 25.03.2014

Jarco P., (2012), Monitoring the Career Paths of the University Graduates as the Quality Instrument in Education, w: International Conference on ICT Management for Global Competitiveness and Economic Growth in Emerging Economies, Wroclaw.

Kawka T.. (2012), Uelastycznienie kształtowania wynagrodzeń w organizacji, Sukces w zarządzaniu kadrami, T1 Problemy zarządczo-ekonomiczne (ed. T. Listwan, M. Stor), Wyd. UE we Wrocławiu.

Kotian J. Arokszallasi Z., Rzentarzewska K, (2014), 25 years after communism - does Central and Eastern Europe still hold the key to growth?, Erste Group Research CEE Special Report, November 11, 25 years after Communism, does CEE still hold key to growth?, www. erstegroup.com/en/.../pi-20141111-report.pdf, 15.08.2015. 
Koźmiński, A. K., (2004), Zarzqdzanie w warunkach niepewności, Warszawa.

Kożusznik B., (2002), Zachowania çłowieka w organiz̧acji, Warszawa.

Mączyński J., Wyspiański D., (2011), Differences on Organizational Practices and Preferred Leader Attributes Between Polish Managers Studies in 2010/2011 and 1996/1997, (ed.) L. Sułkowski, Journal of Intercultural Management, vol. 3.

McKinsey Global Institute, (2013), A new dawn: Reigniting growth in Central and Eastern Europe, http://www.mckinsey.com/insights/economic_studies/a_new_dawn_reigniting_ growth_in_central_and_eastern_europe.pdf, 15.08.2015.

Raport Polska 2030 - wyzwania rozwojowe, (2011), Warszawa 17 listopada.

Ravishankar L., Hudson K., (1999), Badanie cech przywódczych wśród najwyższej kadry

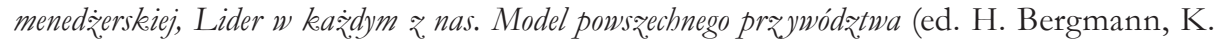
Hudson, D. Russ-Eft), Wydawnictwo Galaktyka, Lódź.

Sikorski C.,(2006), Organizacje bez wodzów. Od przywódz̨twa emocjonalnego do koordynacji demokratycznej, Wyd. C.H. Beck, Warszawa.

Strategia Rozwoju Kraju 2020, (2012), Ministerstwo Rozwoju Regionalnego, Warszawa wrzesień.

Suchodolski A., (2012), Czynniki wptywajace na wytyczanie kierunków rozwoju pracowników w organizacji, Sukces w zarządzaniu kadrami, T1 Problemy zarządczo-ekonomiczne (ed. T. Listwan, M. Stor), Wyd. UE we Wrocławiu.

Wyniki Narodowego Programu Foresight Polska 2020, (2009), Warszawa. 